\title{
О КОНФЕРЕНЦИИ, ПОСВЯЩЕННОЙ 90-летию со дня рождения А.Д. ГРАЧА
}

\author{
(C) 2019 г. Г.А. Базарбаева, Г.С. Джумабекова
}

Заметка кратко знакомит читателей с конференцией, проходившей 10-14 декабря 2018 г. в Санкт-Петербурге и посвященной 90-летию со дня рождения выдающегося археолога А.Д. Грача. Город на Неве является знаковым для казахстанской археологии. Здесь происходило становление таких выдающихся личностей отечественной науки, как Ч.Ч. Валиханов (Ш. Уалиханов), А.Х. Маргулан, К.А. Акишев, А.М. Оразбаев, М.К. Кадырбаев, К.М. Байпаков. Казахстанская делегация представила на конференции доклады, в которых рассматривались различные аспекты изучения памятников раннего железного века Сарыарки.

Ключевые слова: археология, А.Д. Грач, Санкт-Петербург, ИИМК РАН, конференция, доклады

В первой половине декабря минувшего года в Институте истории материальной культуры Российской академии наук (ИИМК РАН) состоялась вторая всероссийская с международным участием конференция «Древние культуры Центральной Азии и Санкт-Петербург», посвященная 90-летию со дня рождения выдающегося исследователя центральноазиатских древностей и европейского города Нового времени Александра Даниловича Грача. Организаторами конференции выступили ИИМК РАН, Государственный Эрмитаж, Музей антропологии и этнографии РАН им. Петра Великого (Кунсткамера) и Русское географическое общество [Интернет-ресурс].

В течение пяти дней, с 10 по 14 декабря, в стенах Русского географического общества, Института истории материальной культуры и Государственного Эрмитажа были за- слушаны доклады исследователей из различных научных центров России, Казахстана, Великобритании (фото).

Примечательным и запоминающимся было открытие конференции, проходившее в историческом здании - в Штаб-квартире Русского географического общества в СанктПетербурге, в переулке Гривцова. Для казахстанской делегации особенно волнительным было то, что среди портретов известных географов, путешественников, первооткрывателей, размещенных на стенах штаб-квартиры, находится портрет нашего соотечественника - Шокана Уалиханова. Возможно, эти стены помнят и другого легендарного человека, стоявшего у основ археологии Казахстана и посвятившего изучению наследия Шокана многие годы жизни, - Аликея Хакановича Маргулана [Бейсенов и др., 2017, с. 17-21; Маргулан Д.А., 2018]. 


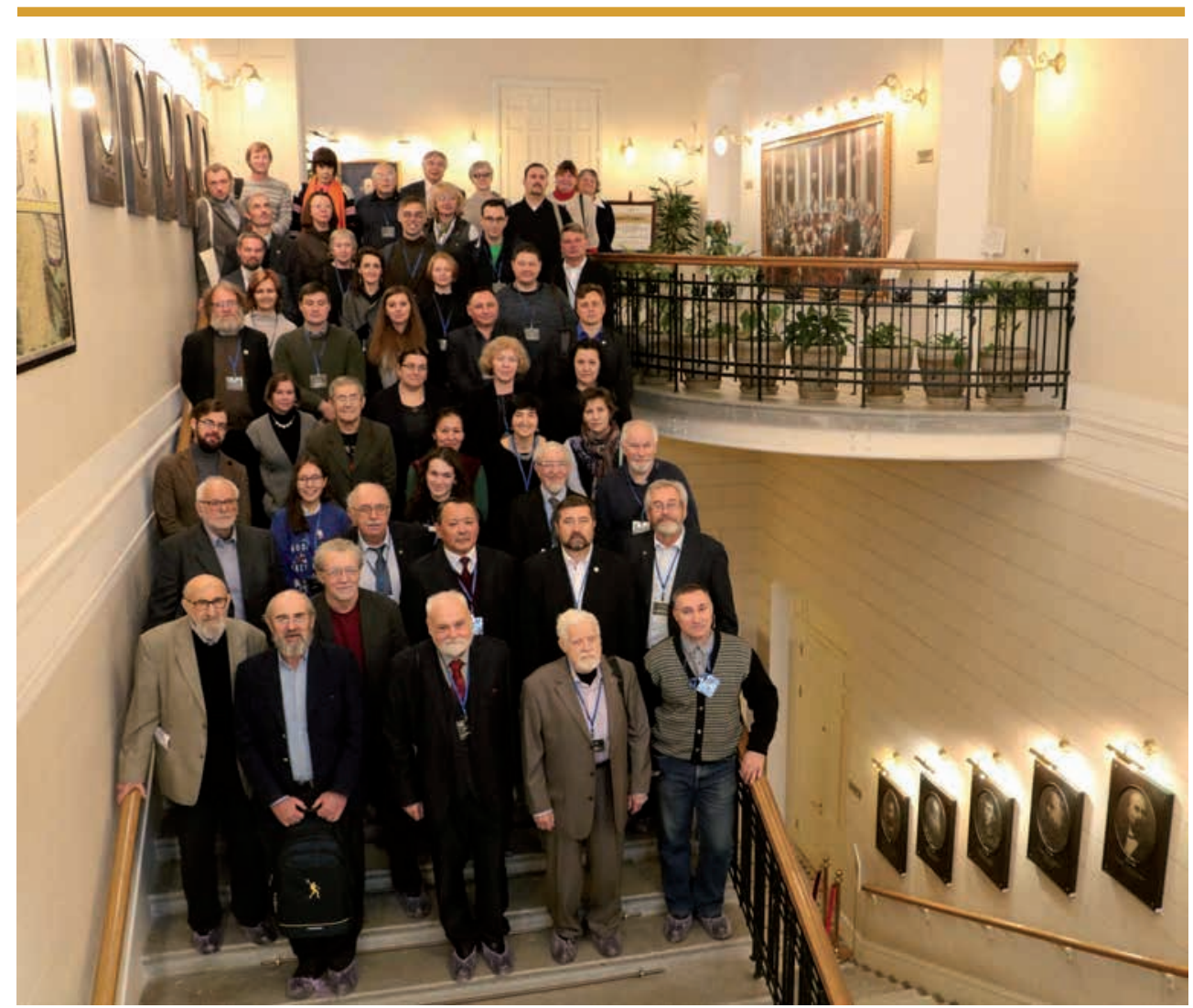

На снимке участники конференщии. (РРсское географическое общество

The conference participants. (C) Russian Geographical Society

Для казахстанской археологии XX века Ленинград/Санкт-Петербург сыграл ключевую роль [Байпаков, 2004; Смирнов, 2017]. Именно в городе на Неве происходило становление таких личностей, как А.X. Маргулан, Е.И. Агеева, К.А. Акишев, А.М. Оразбаев, М.К. Кадырбаев, К.М. Байпаков. Поэтому принять участие в таком мероприятии как конференция памяти А.Д. Грача было очень значимо и ответственно. Ушедшее поколение казахстанских археологов - современники А.Д. Грача, поэтому участие в таких знаковых мероприятиях, приуроченных к юбилеям известных ученых, - скромная дань самоотверженному труду коллег, посвятивших себя науке.
На открытии конференции прозвучало много теплых, ярких воспоминаний об экспедициях, открытиях А.Д. Грача. Этому были посвящены выступления вице-президента Русского географического общества К.В. Чистякова, заместителя генерального директора Государственного Эрмитажа С.Б. Адаксиной, директора ИИМК РАН В.А. Лапшина, а также друзей и ближайших коллег А.Д. Грача - С.Н. Астахова, Д.Г. Савинова, Я.А. Шера.

В сообщении Я.А. Шера было высказано пожелание, адресованное руководству ИИМК РАН, - провести специальное заседание Ученого совета ИИМК РАН и отменить несправедливое решение начала 1970-х гг., 
последствия которого крайне негативно отразились на жизни и научной судьбе А.Д. Грача. Яков Абрамович просил коллег поддержать его предложение* [*Подробно с ситуацией можно ознакомиться из материалов сборника, посвященного 70-летию А.Д. Грача - прим. авт.] [Древние культуры..., 1998].

Каждый день конференции был насыщен выступлениями исследователей и сопровождался бурными, заинтересованными обсуждениями. Доклады казахстанской делегации были посвящены вопросам изучения памятников раннего железного века Центрального Казахстана, в том числе искусства раннесакского времени. В двух сообщениях А.З. Бейсенова были изложены основные результаты исследований тасмолинской культуры, а также работ на поселении Абылай. Первый доклад был посвящен осмыслению научного вклада в изучение древних культур Казахстана и Тувы двух современников - А.Д. Грача и М.К. Кадырбаева. Оба исследователя прожили короткую жизнь, но оставили глубокий след в археологии Центральной Азии. А.Д. Грач и М.К. Кадырбаев являются первооткрывателями ключевых культур сакского времени - алды-бельской в Туве и тасмолинской - в Сарыарке.

В своем выступлении А.3. Бейсенов отметил факты обнаружения в Центральном Казахстане серии статуарных изображений эпохи палеометалла. В своем комментарии А.В. Варёнов, возвращаясь к находкам, сделанным А.Х. Маргуланом и названных им «бараньими» (койтас) или «медвежьими» (аютас) камнями, отметил любопытную параллель - оленные камни в Монголии в среде местного населения известны как «овечьи камни».
Наиболее запоминающимися были доклады М.Е. Килуновской, Т.Р. Садыкова, П.М. Леуса и Е.А. Миклашевич, в которых были отражены результаты исследований территорий, оказавшихся затопленными в связи со строительством СаяноШушенской и Красноярской ГЭС. Спасательные исследования археологи вынуждены были проводить в самые короткие сроки - в перерывах от спуска до подъема воды в водохранилищах.

Представительной была делегация из Алтайского государственного университета (г. Барнаул). Хронологические рамки озвученных сообщений охватывают период от эпохи бронзы до средневековья. Доклад руководителя делегации А.А. Тишкина был посвящен междисциплинарному изучению металлических изделий из раннесредневекового комплекса в Верхнем Приобье.

Интерес слушателей вызвало сообщение Н.Н. Серёгина о результатах анализа типологического развития стремян в культуре населения Центральной Азии первой половины I тыс. н.э. Дискуссионные вопросы, касающиеся снаряжения верхового коня затрагивались также в докладе В.П. Никонорова и И.А. Аржанцевой.

Блок докладов был посвящен изучению вопросов скифо-сакского искусства. Так, в сообщении А.Р. Канторовича рассматривались особенности «зооморфных превращений» в искусстве раннего железного века Евразии. Высказана была интересная мысль относительно бляшек в виде изображений орла из Шиликты (курганы № 5, «Байгетобе»), Талды-2 (курган № 2) - по мнению А.Р. Канторовича орёл изображен с жертвой в когтях. 
Доклад В.А. Киселя содержал результаты исследования предметов древнего искусства из кургана Аржан-2. По его мнению, традиция плакировки железных изделий золотом происходит из Китая. Вопросы изучения звериного стиля кургана Аржан-2 были затронуты в сообщении Е.В. Переводчиковой. В частности, ею была сделана попытка обратить внимание коллег на дату кургана.

Новые сведения были представлены в серии докладов, посвященных гуннской тематике и озвученных С.С. Миняевым, П.М. Леусом, Н.А. Сутягиной.

Среди выступлений, прозвучавших во время обсуждения докладов, запоминающейся была речь Д.Г. Савинова. Как оказалось, к изучению восточноказахстанских древностей и выделению куртусского этапа в хронологии раннего железного века Алтая Дмитрий Глебович приложил руку в прямом смысле этого слова. По воспоминаниям Д.Г. Савинова руководитель раскопок С.С. Сорокин на могильнике Курту доверил двум студентам расчищать погребение с конем: «любимчику» - Б.Н. Пяткину досталась расчистка скелета человека, а Д.Г. Савинову - коня.

В обсуждении докладов в контексте анализа техники до- мостроительства в эпоху бронзы В.А. Алёкшин в качестве примера привел данные по памятнику нуринской культуры Шагалалы (Чаглинка), исследовавшемуся археологами А.М. Оразбаевым, Т.С. Малютиной, М.К. Хабдулиной, С.К. Сакеновым. По мнению исследователей, материалы поселения предоставляют возможность прояснить более общие вопросы взаимодействия населения Степи и Средней Азии.

В целом, на конференции затрагивались различные вопросы: происхождения, генезиса, преемственности и взаимодействия культур; хронологии и периодизации; охраны и использования памятников археологии, истории науки.

Особо следует отметить работу, проделанную организаторами конференции - Д.Г. Савиновым, Н.Ю. Смирновым, М.Е. Килуновской, Н.А. Боковенко, К.В. Чугуновым, А.В. Поляковым, В.С. Бусовой, В.П. Лурье и многими другими. Благодаря их усилиям была создана располагающая к обсуждениям, конструктивному диалогу, плодотворным дискуссиям дружеская атмосфера. Участие в подобных мероприятиях, несомненно, обогащает новой информацией, встречами, книгами, служит своеобразным стимулом к дальнейшим исследованиям.

\section{ЛИТЕРАТУРА}

1. Байпаков К.M. Казахстанская археологическая школа и Санкт-ПетербургЛенинград // Известия НАН РК. Сер. обществ. наук. 2004. № 1 (242). С. 17-22.

2. Бейсенов А.З., Джумабекова Г.С., Базарбаева Г.А. Путь к изучению древностей центра страны: история создания первой археологической экспедиции Казахской Академии наук // Археологическое наследие Центрального Казахстана: изучение и сохранение: сб. научн. ст., посвящ. 70-летию организации Центрально-Казахстанской археологической экспедиции Академии наук Казахстана / А.З. Бейсенов, В.Г. Ломан (отв. ред.). Алматы: НИЦИА «Бегазы-Тасмола», 2017. Т. 1. С. 11-64. 
Базарбаева Г.А., Джумабекова Г.С. О конференции, посвященной 90-летию со дня рождения А.Д. Грача

3. Древние культуры Центральной Азии и Санкт-Петербург: матер. всерос. научн. конф., посвящ. 70-летию со дня рождения А.Д. Грача. СПб.: Культ-информ-пресс, $1998.304 \mathrm{c}$.

4. Интернет-ресурс. Официальный сайт ИИМК РАН. Древние культуры Центральной Азии. URL: http://www.archeo.ru/hronika-1/konferencii-1/drevnie-kultury-centralnoi-azi/drevnie-kultury-centralnoi-azi

5. Маргулан Д.А. Жизнь и научная деятельность А.Х. Маргулана. Образ ученого и человека // Қазақстан археологиясы. 2018. № 1-2. С. 37-47.

6. Смирнов Н.Ю. Один на всех. К эпистолярным связям М.П. Грязнова и лидеров казахской археологии второй половины XX века // Археологическое наследие Центрального Казахстана: изучение и сохранение: сб. научн. ст., посвящ. 70-летию организации Центрально-Казахстанской археологической экспедиции Академии наук Казахстана / А.З. Бейсенов, В.Г. Ломан (отв. ред.). Алматы: НИЦИА «Бегазы-Тасмола», 2017. T. 1. C. $230-247$.

\section{Сведения об авторах:}

Базарбаева Галия Аппазовна - ведущий научный сотрудник, Институт археологии им. А.Х. Маргулана (г. Алматы, Казахстан); galiya2002@gmail.com

Джумабекова Гульнара Саиновна - ведущий научный сотрудник, Институт археологии им. А.Х. Маргулана (г. Алматы, Казахстан); gdzhuma@mail.ru

\section{А.Д. Грачтың 90 жасына арналған конференция жайында}

\section{Ғ.А. Базарбаева, Г.С. Джумабекова}

Хабарлама 2018 жылдың 10-14 желтоқсанында Санкт-Петербор қаласында өткен көрнекті археолог А.Д. Грачтың туылғанына 90 жыл толуына арналған конференциямен қысқаша таныстырады. Нева жағалауындағы қала Қазақстан археологиясы үшін ерекше болып табылады. Бұл жерде Ш.Ш. Уәлиханов, Ә.Х. Марғұлан, К.А. Ақышев, А.М. Оразбаев, М.Қ. Қадырбаев, К.М. Байпақов сияқты отандық ғылымдадың атақты тұлғалары қалыптасты. Конференцияда қазақстандық ғалымдар Сарыарқаның ерте темір дәуірі ескерткіштерін зерттеу мәселелері бойынша баяндама жасады.

Түйін сөздер: археология, А.Д. Грач, Санкт-Петербор, ММТИ, баяндамалар

\section{ON THE CONFERENCE dedicated to the $90^{\text {th }}$ anniversary of A.D. GRACH}

\section{G. A. Bazarbayeva, G.S. Jumabekova}

The note briefly introduces the conference held on 10-14 December 2018 in Saint Petersburg and dedicated to the $90^{\text {th }}$ anniversary of the eminent archaeologist A.D. Grach. The city on the Neva is a landmark for Kazakhstan archaeology. Here was the emergence of such eminent personalities of the national science as Ch.Ch. Valikhanov, A.Kh. Margulan, K.A. Akishev, A.M. Orazbayev, M.K. Kadyrbayev, K.M. Baipakov. The Kazakhstan delegation presented at the conference reports on the study of Saryarka monuments of the early Iron Age.

Keywords: archaeology, A.D. Grach, Saint Petersburg, Institute of the History of Material Culture of the Russian Academy of Sciences, conference, archaeologists, reports

\section{REFERENCES}

1. Baipakov, K. M. 2004. In Izvestiya NAN RK (News of the National Academy of Sciences of Kazakhstan), 1 (242), 17-22 (in Russian).

2. Beisenov, A. Z., Jumabekova, G. S., Bazarbayeva, G. A. 2017. In Beisenov, A. Z., Loman, V. G. (eds.) Arheologicheskoe nasledie Tsentralnogo Kazahstana (Archaeological heritage of Central Kazakhstan). Almaty: «Begazy-Tasmola», 1, 11-64. (in Russian). 
3. Drevnie kultury Centralnoi Azii i Sankt-Peterburg (Ancient cultures of Central Asia and St. Petersburg: mater. scientific conf., dedicated. 70th anniversary of the birth of A.D. Grach). 1998. Saint Petersburg: Kult-inform-press Publ. (in Russian).

4. Internet-resurs. Drevnie kultury Tsentralnoi Azii (Ancient cultures of Central Asia). URL: http://www.archeo.ru/hronika-1/konferencii-1/drevnie-kultury-centralnoi-azi/drevniekultury-centralnoi-azi

5. Margulan, D. A. 2018. In Kazakhstan archeology, 1-2, 37-47 (in Russian).

6. Smirnov, N. Yu. 2017. In Beisenov, A. Z., Loman, V. G. (eds.) Arheologicheskoe nasledie Tsentralnogo Kazahstana (Archaeological heritage of Central Kazakhstan). Almaty: «Begazy-Tasmola», 1, 230-247 (in Russian).

\section{About the Authors:}

Bazarbayeva Galiya A. Leading Researcher, A.Kh. Margulan Archeology Institute Kazakhstan,galiya2002@gmail.com

Jumabekova Gulnara S. Leading Researcher, A.Kh. Margulan Archeology Institute, Almaty, Kazakhstan, gdzhuma@mail.ru 